\title{
Combined effect of prebiotics and probiotics on growth performance and feed utilization of Nile tilapia (Oreochromis niloticus).
}

\author{
Hussein, M. S.; Elzayat, A. M. and El-Nawsany, M. M.
}

Fish production, Animal Production Department, Faculty of Agric. Cairo, AlAzhar University

\begin{abstract}
Citric acid and Bacillus subtilis are widely used in diets of fish as prebiotic and probiotic for improved growth performance and enhanced immune response. This study aims to investigation of used Bacillus subtilis and combination between Citric acid and Bacillus subtilis in diets of Nile tilapia (O. niloticus) juveniles and affected on Histopathology and morphometric assessment of intestine, growth, feed utilization and body composition. Nile tilapia were fed control diet (D1) without addition, additive Bacillus subtilis (BS) at a rate $10 \mathrm{~cm} / \mathrm{kg}$ diet (D2), $10 \mathrm{~cm}(\mathrm{BS})+5 \mathrm{~g}$ citric acid $/ \mathrm{kg}$ diet (D3) and $10 \mathrm{~cm}(\mathrm{BS})+10 \mathrm{~g}(\mathrm{CA}) / \mathrm{kg} \operatorname{diet}(\mathrm{D} 4)$ for 90 days. Results showed that morphometric assessment of intestine improved and significant difference in duodenum, jejunum and ileum in mucosal length and villi length between all treatments except mucosal length in duodenum. Also, these results showed the highest values and best group D4 to contain $(10 \mathrm{~cm} \mathrm{BS}+10 \mathrm{~g}$ $\mathrm{CA})$ followed by $\mathrm{D} 3$ to contain $(10 \mathrm{~cm} \mathrm{BS}+5 \mathrm{~g} \mathrm{CA})$ and the lowest values showed in control group (D1). Also, histopathology of intestine showed that duodenum, jejunum and ileum of fish from group control and D2 showing normal villi and normal mucosal lining. On the other hand, results of intestine of fish from group D3 and D4 showing increase the villi length in duodenum, increase the villi length and branches in jejunum and normal mucosal lining in ileum. Results of body weight gain, SGR, condition factor, FCR, FE, PER, PPV and chemical composition of fish showed improvement and significant differences $(\mathrm{P} \geq 0.05)$ between all treatments contain citric acid and Bacillus subtilis compared to control. This suggests that citric acid and Bacillus subtilis in diet had a
\end{abstract}


synergistic effect on histopathology and morphometric assessment of intestine, growth performance, feed utilization and body composition of Nile tilapia (O. niloticus) juveniles.

Keywords: Nile tilapia, morphometric intestine, citric acid, Bacillus subtilis.

\section{INTRODUCTION}

While tilapia has been cultured since the early 1950s, it has become increasingly popular recently and is currently second only to carp in terms of total world production. For this reason, it is often referred to as 'aquatic chicken' or the 'poor man's fish'. Tilapia farming has now spread across a wide range of culture systems - from small ditches to large ponds and reservoirs, in fresh and seawater, from peri-urban to rural areas. Tilapia plays a significant role in food security because it is consumed by the poor, especially those residing in rural areas, as well as by the inhabitants of urban areas, who buy their foods from supermarkets. Tilapia has therefore become 'everyone's fish'. It now directly or indirectly contributes to the livelihood of these people by supplying cheap animal protein, providing employment and generating income. Although tilapia is originally from Africa, they have now been accepted in most countries of Asia and Latin America. Nile tilapia (Oreochromis niloticus) became a focus species although there are over 200 species available for culture in different parts of the world. There were several underlying reasons for this. In Thailand, Nile tilapia has a special history (Ram C. Bhujel, 2014). The protection and cure of the infectious aquatic animal-diseases, in Egypt, include a limited number of Government-approved antibiotics. However, the use of antibiotics can lead to the evolution of antibiotic-resistant bacterial strains (FAO, 2006) and may modified the immune response of fish (Lundén $\boldsymbol{e t}$ al. 2002). Probiotics, known as beneficial microbes, are being proposed as an effective and eco-friendly alternative to antibiotics. They were first applied in aquaculture species more than three decades ago, but considerable attention had been given only in the early 2000s. Probiotics is one of the idefinition alternatives that can lessen the reliance of the fish production to antibiotics (Verschuere et al. 2000; Nayak, 2010; Lazado \& Caipang, 2014a, 2014b; Akhter et al. 2015). Bacillus subtilis ( $B$. subtilis) has been shown to possess antitumor and immunomodulatory activities (Cohen et al. 2003). Some studies have demonstrated that B. subtilis and spores of B. subtilis act as probiotics by promoting the growth and viability of the beneficial lactic acid bacteria in the intestinal tracts of humans and some animals (Hoa et al. 2000). Citric acid (CA) is an organic acid widely applied in food and pharmaceuticals industry. CA can enhance 
digestive function and alleviate stress, which has been reported in land animals such as pig (Partanen and Mroz 1999; Øverland $\boldsymbol{e t}$ al. 2000, 2008; Partanen et al. 2002) and broiler chick (Brenes et al. 2003; Gauthier 2005), but relatively few studies were reported in aquatic animals. The improvement in growth and nutrients digestibilities by dietary CA was also reported in tilapia, Oreochromis niloticus $x$ O. aureus (Pan et al. 2004), allogynogenetic crucian carp, Carassius auratus gibelio (Leng et al. 2006), rainbow trout, Oncorhynchus mykiss (Sugiura et al. 2001; Pandey and Satoh 2008) and red sea bream, Pagrus major (Sarker et al. 2005). Therefore, the present study aimed to investigate the effect of probiotic and citric acid supplementation on Histopathology and morphometric assessment of intestine, growth, feed utilization and body composition in Nile tilapia (O. niloticus) juveniles.

\section{MATERIAL AND METHODS}

\section{Aimed and location:}

The present study was carried out at the Fish Experimental Station belonging to the Department of Animal Production, Faculty of Agriculture, Al-Azhar University, Cairo, Egypt. The aim of the experiment is to investigate the effect of probiotic (Bacillus subtilis) and prebiotic (citric acid) on diets of Nile tilapia in growth performance, feed utilization and body composition.

\section{Description of experimental aquaculture units:}

Fish were reared in cement ponds $\left(1 \times 4 \times 1 \mathrm{~m}^{3}\right)$ with a uniform size and weight were at a density of $20 \mathrm{fish} / \mathrm{m}^{3}$ (each pond $4 \mathrm{~m}^{3}$ ). All experimental ponds were supplied with air through an aeration system which connected with air pump (5hp). In the present study two additive feed in diets Bacillus subtilis $(\mathrm{BS})$ at a rate $10 \mathrm{~cm} / \mathrm{kg}$ diet, $10 \mathrm{~cm}(\mathrm{BS})+5 \mathrm{~g}$ citric acid $/ \mathrm{kg}$ diet, $10 \mathrm{~cm}$ (BS) $+10 \mathrm{~g}(\mathrm{CA}) / \mathrm{kg}$ diet and control.

\section{Experimental fish:}

The fish used in this study were Nile tilapia (O. niloticus) juveniles, were purchased from the Prof. Dr.Ismaiel Radwan fish Farm, Kafr El-Sheikh Governorate., Egypt. The experimental fish were transported at early morning using a special fish transport car with aeration facilities. They were acclimated to 14 days before starting the experiment thereafter. 960 fish were randomly distributed in four experimental dietary groups in 4 ponds and stocked at a density $20 \mathrm{fish} / \mathrm{m}^{3}$ with an average initial weight of $0.5 \mathrm{~g} /$ fish.

\section{Feeding rate and techniques:}


Feeding ration amounted to $4 \%$ of total body weight daily at the experiment period (12 weeks). Diets were fed to each group in the form of dried suitable to the fish size. Fish were fed 6 days/week and the amount of feed was divided into two equal portions at 9 am and $2 \mathrm{pm}$. Every fourteen days, the fish in each tank was weighed and the amount of feed was corrected according to the new fish biomass throughout the experimental period (Annet, 1985).

\section{Experimental diets:}

Four experimental diets were formulated to contain about $30 \%$ crude protein and $4700 \mathrm{kcal} / \mathrm{kg}$ gross energy. The first diet Table (1) had served as a control diet (D1) and contained mainly of herring meal; soybean meal and wheat bran. Elsewhere, the experimental diets 2 (D2) contained the same diet of control and additive probiotic Bacillus subtilis (BS) at a rate $10 \mathrm{~cm} / \mathrm{kg}$ diet. Also, the experimental diets 3 (D3) contained $10 \mathrm{~cm}(\mathrm{BS})+5 \mathrm{~g}$ citric acid/kg diet the experimental diets 4 (D4) contained $10 \mathrm{~cm}(\mathrm{BS})+10 \mathrm{~g}$ (CA)/kg diet to investigate the effect of probiotics and citric acid on growth performance and feed utilization of red hybrid tilapia (O. niloticus $x O$. mosambicus) fingerlings.

\section{Chemical analysis of fish:}

At the beginning of feeding trial, a total number of 10 fingerlings were netted, weighed and immediately kept in a deep freezer $\left(-18^{\circ} \mathrm{C}\right)$ for chemical analysis (as zero group). A similar procedure was applied at the end of such experimental period (five fingerlings as final samples of each treatment). Samples of each treatment were separately and dried at $65^{\circ} \mathrm{C}$ for $24 \mathrm{hrs}$. Then ground in a mixer. Representative samples were chemically analyzed according to A.O.A.C. (2005) methods, while their energy contents were calculated according to NRC (1993).

\section{Growth performance parameters:}

Fish growth performance, weight gain, average body weight gain, condition factor and specific growth rate were determined according to Recker, (1975) and Castell \& Tiews, (1980) as following equations:

1. Body weight gain $(\mathrm{BWG})=(\mathrm{W} 1)-(\mathrm{W} 0)$

Where:

W1: mean final weight W0: mean initial weight

2. Condition factor $(\mathrm{K})=\mathrm{FW} / \mathrm{FL} 3 \times 100$

Where:

FW: Final body weight (g) FL3: Final body length $\left(\mathrm{cm}^{3}\right)$ 
3. Specific growth rate $(\mathrm{SGR}, \% /$ day $)=[\mathrm{Ln} \mathrm{W} 1-\mathrm{Ln} \mathrm{W} 0 / \mathrm{T}] 100$ Where:

Ln : the natural $\log \mathrm{W} 1$ : final weight at the certain period $(\mathrm{g})$

W0: initial weight at the same period $(\mathrm{g})$

$\mathrm{T}$ : experimental period (day)

Table (1): The composition and proximate analyses of basal diet

\begin{tabular}{c|c|c|c|c}
\hline Items & D1 & D2 & D3 & D4 \\
\hline Fish meal & 8 & 8 & 8 & 8 \\
Glutein & 20 & 20 & 20 & 20 \\
Soybean meal & 25 & 25 & 25 & 25 \\
Wheat bran & 7 & 7 & 7 & 7 \\
Corn & 35 & 35 & 35 & 35 \\
*Vit \& Min .Mix & 2 & 2 & 2 & 2 \\
Citric acid (g/kg diet) & 0 & 0 & 5 & 10 \\
Bacillus subtilis (cm/kg diet) & 0 & 10 & 10 & 10 \\
Linseed Oil & 6 & 6 & 6 & 6 \\
(CMC) carboxy methyl & 2 & 2 & 2 & 2 \\
cellulose & & & & \\
Total & 100 & 100 & 100 & 100 \\
\hline proximate analysis of diets & & \\
\hline Dry matter (DM) \% & 91.27 & 90.92 & 90.82 & 90.68 \\
Crude protein(CP) \% & 30.09 & 30.05 & 30.03 & 30.01 \\
Ether extract(EE) \% & 12.99 & 13.38 & 13 & 13.22 \\
Crude five(CF) \% & 4.44 & 4.42 & 4.43 & 4.41 \\
Ash\% & 8.32 & 6.89 & 7 & 8.18 \\
**NFE\% & 44 & 45.2 & 45.5 & 44.1 \\
***GE(Kcal/100g)3 & 470.51 & 479.11 & 476.2 & 472.53 \\
****DG(Kcal/100g)3 & 352.88 & 359.33 & 357.15 & 354.40 \\
\hline
\end{tabular}

* Vitamin \& mineral mixture/kg premix: Vitamin D, 0.8 million IU; A, 1.33g; D3, 1.68g; E, 6.66g; C, 16.8g; k, 0.8g; B1, 0.4g; Riboflavin 3.75g; B6 2.45g; B12, .33mg; NI, 9.42g; Pantothenic acid, 12.42g; Folic acid, 0.68g; Biotin, 16.6mg; BHT, 0.5g; Mn, 14.7g; Zn, $31.6 \mathrm{~g}$; Fe, 18.3g; 1, 0.62g; Selenium, 0.22g and Co, 6.8mg.

** Calculated by differences [Nitrogen free extract (NFE) $=[100-(\mathrm{CP}+\mathrm{EE}+\mathrm{CF}+\mathrm{Ash})]$. *** Gross energy value was calculated from their chemical composition, Estimated according to Jobling, (1983). As 5.64, 9.44 and $4.11 \mathrm{Kcal} / \mathrm{g}$ for protein, lipid and NFE, respectively.

**** Digestible energy, estimated according to Jobling, (1983), using digestible energy = gross energy X 0.75 .

\section{Feed efficiency parameters:}


1. Feed intake $(\mathrm{FI})=$ fish weight $\mathrm{x}$ (feeding level/100) $\mathrm{x}$ number of days

2. Feed conversion ratio (FCR) (Tacon, 1987): The feed conversion ratio (FCR) was expressed as the proportion of dry food consumed per unit live weight gain of fish.

FCR $=$ Feed intake $(\mathrm{g}) /$ weight gain $(\mathrm{g})$.

3. Protein efficiency ratio (PER) (Davies \& Morries 1997):

$(\mathrm{PER})=$ Weight gain $(\mathrm{g}) /$ Protein intake $(\mathrm{g})$

4. Feed efficiency (FE)

$(\mathrm{FE} \%)=[$ Weight gain $(\mathrm{g}) /$ Feed intake $(\mathrm{g})]$

5. Protein productive value (PPV) (Marias and Kissil, 1979): $(\mathrm{PPV} \%)=[\mathrm{PR} 1-\mathrm{PR} 0 / \mathrm{PI}] 100$

Where:

PR1 : is the total fish body protein at the end of the experiment. (On dry matter basis)

PR0: is the total fish body protein at the start of the experiment. (On dry matter basis)

PI: Protein intake.

\section{Histopathology and morphometric assessment of intestinal villi absorptive capacity:}

Samples from the different intestinal portions were collected from fish of different groups, and then fixed in 10\% neutral buffered formalin. After dehydration and clearance, the tissues were embedded in paraffin and sectioned in $5 \mu \mathrm{m}$ thickness. The serial sections were subjected to staining with hematoxylin and eosin (Bancroft et al., 2013).

The morphometric analysis was performed using Image $\mathrm{J}$ analysis software (National Institutes of Health, MD, USA), whereas the villus height (measured from the tip of the villus to the villus- crypt junction), villus width from the mid of the villus and crypt depth (measured from the cryptvillus junction to the base of the crypt).

\section{Statistical analysis:}

Results are the mean values of duplicates. SPSS 20.0 INC., Chicago, IL, USA (SPSS, 2011) was used to perform statistical calculations. All data were subjected to one-way analysis of variance (ANOVA) followed by the Duncan's post hoc multiple test at a 5\% probability level (Duncan, 1955). 


\section{RESULTS AND DISCUSSION}

\section{Growth performance:}

Results revealed that, the average values of initial weights and lengths at the start of the experiment were 5.6 \pm 0.02 , with insignificant differences among the experimental period, indicating the complete randomization of individual fish among the experimental trials at the start of the experiment and were homogenous.

Results (Table 2) showed that, at the end of the experimental period (12 weeks), the maximum final weights were achieved in the experimental fish fed diets containing $10 \mathrm{~cm}$ Bacillus subtilis and $10 \mathrm{~g}$ citric acid and had a significantly $(\mathrm{P}>0.05)$ higher total weight gain compared to the control diet and the rest of the experimental diets. However, the lowest growth performance was observed in the experimental fish fed the experimental diet (D1) control diet with an average final weight of $64.95 \pm 0.15(\mathrm{~g})$ compared to the other of the experimental diets. Final fish weight and growth performance indicated that, additive Bacillus subtilis and citric acid in diets of fish showed positive effects on growth performance of Nile tilapia (O. niloticus) fingerlings and improvement in body weight. The present study showed that, the mean final weight, weight gain (WG), daily weight gain (DWG), specific growth rate (SGR) and condition factor (K) of the fish fed diets containing Bacillus subtilis and citric acid were significantly $(\mathrm{p}<0.05)$ than that of fish fed with the control diet. Found significant differences $(\mathrm{P}>0.05)$ in survival rate were group (1) (97\%), group (2) (98\%), group (3) (99\%) and group (4) (100\%). experimental groups.

\section{Feed utilization:}

Feed conversion ratio (FCR), feed efficiency (FE), Protein retention (PR), protein efficiency ratio (PER), Protein retention (PR) and protein productive value (PPV) are shown in table (3). All variables related to feed utilization efficiencies such as feed conversion ratio and protein efficiency ratio in all experimental diets were influenced by dietary treatments. Feed utilization of Nile (O. niloticus) fingerlings was improved slightly when fed with diets containing Bacillus subtilis and citric acid without significant differences among them $(\mathrm{P}>0.05)$ except the control diet, while significant increased were obtained with the increase in Bacillus subtilis and citric acid rate. 
Table (2): Effect of additive Bacillus subtilis and citric acid in diets on growth performance of the Nile tilapia (O. niloticus).

\begin{tabular}{|c|c|c|c|c|}
\hline Parameters & D1 (Control) & D2 (10cm BS) & D3 $(10 \mathrm{~cm} \mathrm{BS+5g}$ & D4 $(10 \mathrm{~cm} \mathrm{BS}+10 \mathrm{~g}$ \\
\hline Initial fish weight (g) & $5.6 \pm 0.03$ & $5.1 \pm 0.05$ & $5.2 \pm 0.02$ & $5.4 \pm 0.01$ \\
\hline Final fish weight (g) & $64.95 \pm 0.15^{c}$ & $67.30 \pm 0.10^{b}$ & $68.35 \pm 0.25^{\mathrm{ab}}$ & $69.70 \pm 0.90^{\mathrm{a}}$ \\
\hline Total weight gain (g) & $59.95 \pm 0.15^{c}$ & $62.30 \pm 0.10^{b}$ & $63.35 \pm 0.25^{\mathrm{ab}}$ & $64.70 \pm 0.90^{\mathrm{a}}$ \\
\hline AV. Daily gain (g) & $0.67 \pm 0.01^{c}$ & $0.69 \pm 0.03^{b}$ & $0.71 \pm 0.02^{a b}$ & $0.72 \pm 0.01^{\mathrm{a}}$ \\
\hline SGR (\%/ day) & $2.39 \pm 0.09^{c}$ & $2.42 \pm 0.2^{b}$ & $2.44 \pm 0.09^{\mathrm{ab}}$ & $2.46 \pm 0.07^{a}$ \\
\hline Condition factor $(\mathbf{K})$ & $1.83 \pm 0.05^{\mathrm{a}}$ & $1.62 \pm 0.02^{b c}$ & $1.58 \pm 0.01^{c}$ & $1.72 \pm 0.01^{\mathrm{ab}}$ \\
\hline No. of fish at start. & 240 & 240 & 240 & 240 \\
\hline No. of fish at end. & 235 & 236 & 238 & 240 \\
\hline Survival ratio (SR \%) & 97 & 98 & 99 & 100 \\
\hline
\end{tabular}


Table (3): Effect of additive Bacillus subtilis and citric acid in diets on the feed utilization of the Nile tilapia $(O$. niloticus)

\begin{tabular}{|c|c|c|c|c|}
\hline Parameters & D1 (Control) & D2 (10cm BS) & D3 $(10 \mathrm{~cm} \mathrm{BS+5g}$ & D4 $(10 \mathrm{~cm} \mathrm{BS}+10 \mathrm{~g}$ \\
\hline Feed intake (g diet/fish) (FI) & $74.66 \pm 0.23^{b}$ & $75.76 \pm 0.95^{\mathrm{ab}}$ & $76.09 \pm 0.12^{a b}$ & $76.78 \pm 0.32^{\mathrm{a}}$ \\
\hline Feed conversion ratio $(\mathrm{FCR})$ & $1.25 \pm 0.01^{\mathrm{a}}$ & $1.22 \pm 0.02^{\mathrm{ab}}$ & $1.20 \pm 0.01^{b}$ & $1.19 \pm 0.01^{b}$ \\
\hline Feed efficiency (FE) (g/ fish) & $0.80 \pm 0.01^{b}$ & $0.82 \pm 0.01^{\mathrm{ab}}$ & $0.84 \pm 0.03^{a}$ & $0.84 \pm 0.01^{\mathrm{a}}$ \\
\hline Protein efficiency ratio (PER) & $2.68 \pm 0.03^{b}$ & $2.74 \pm 0.04^{a b}$ & $2.78 \pm 0.01^{\mathrm{a}}$ & $2.81 \pm 0.02^{\mathrm{a}}$ \\
\hline Protein retention (PR \%) & $8.66 \pm 0.19^{b}$ & $10.29 \pm 0.13^{a}$ & $10.74 \pm 0.27^{\mathrm{a}}$ & $11.06 \pm 0.71^{\mathrm{a}}$ \\
\hline Protein productive value & $38.63 \pm 0.76^{b}$ & $45.28 \pm 1.15^{a}$ & $47.03 \pm 1.23^{\mathrm{a}}$ & $48.01 \pm 1.91^{\mathrm{a}}$ \\
\hline
\end{tabular}




\section{Chemical composition of the whole body experimental fish:}

At the start and end of the feeding trial, proximate composition of whole fish body values for fish fed with experimental diets is given in Table (4). At the end of the experiment, significant differences were detected in the whole body dry matter $(26.88-27.42 \%)$. Results showed significant difference in protein (52.98 - 63.11\%; dry matter), lipid (21.42 - $28.85 \%$; dry matter), ash no significant difference $(14.74-17.63 \%$; dry matter) contents of fish fed with the different experimental diets $(\mathrm{P}>0.05)$.

\section{Morphometric assessment of intestinal villi absorptive capacity}

Results of morphometric assessment of intestine showed that improved and significant difference in duodenum, jejunum and ileum in mucosal length and villi length between all treatments except mucosal length in duodenum. Also, these results showed the highest values and best group D4 to contain $(10 \mathrm{~cm} \mathrm{BS}+10 \mathrm{~g} \mathrm{CA})$ followed by D3 to contain $(10 \mathrm{~cm} \mathrm{BS}+5 \mathrm{~g}$ $\mathrm{CA}$ ) and the lowest values showed in control group (D1)

\section{Histopathology assessment of intestinal villi absorptive capacity}

Results of histopathology of intestine showed that duodenum, jejunum and ileum of fish from group control and supplemented with $10 \mathrm{~cm}$ BS diet showing normal villi and normal mucosal lining (Fig. 1and Fig. 2). On the other hand, results of intestine of fish from group supplemented with $10 \mathrm{~cm}$ $\mathrm{BS}+5 \mathrm{~g} \mathrm{CA}$ and $10 \mathrm{~cm} \mathrm{BS}+10 \mathrm{~g}$ CA showing increase the villi length in duodenum, increase the villi length and branches in jejunum and normal mucosal lining in ileum (Fig. 3 and Fig. 4). 
Table (4): Effect of additive Bacillus subtilis and citric acid in diets on Whole body chemical composition of the Nile tilapia (O. niloticus)

\begin{tabular}{|c|c|c|c|c|c|}
\hline Proximate & Initial & D1 (Control) & D2 $(10 \mathrm{~cm}$ BS $)$ & D3 $(10 \mathrm{~cm} \mathrm{BS}+5 \mathrm{~g}$ & D4 $(10 \mathrm{~cm}$ BS $+10 \mathrm{~g}$ \\
\hline Dry matter (DM) & $78.52 \pm 0.54$ & $27.42 \pm 1.03^{b}$ & $27.86 \pm 0.46^{b}$ & $28.17 \pm 0.96^{b}$ & $26.88 \pm 1.03^{b}$ \\
\hline Crude protein $(\mathrm{CP})$ & $54.44 \pm 0.78$ & $52.98 \pm 1.0^{\mathrm{e}}$ & $59.03 \pm 0.34 b^{c}$ & $59.81 \pm 0.88^{b}$ & $63.11 \pm 0.57^{\mathrm{a}}$ \\
\hline Ether extract (EE) & $20.87 \pm 0.93$ & $28.85 \pm 0.66^{a}$ & $24.31 \pm 0.30^{c}$ & $23.36 \pm 0.52^{c}$ & $21.42 \pm 0.53^{d}$ \\
\hline $\operatorname{Ash}(\%)$ & $24.23 \pm 1.08$ & $17.63 \pm 1.63^{\mathrm{ab}}$ & $15.97 \pm 0.20^{\mathrm{ab}}$ & $15.92 \pm 0.94 a^{b}$ & $14.74 \pm 0.29^{b}$ \\
\hline
\end{tabular}

\begin{tabular}{|c|c|c|c|c|c|c|}
\hline Intestine part & \multicolumn{2}{|c|}{ Duodenum } & \multicolumn{2}{|c|}{ Jejunum } & \multicolumn{2}{|c|}{ Ileum } \\
\hline TRT & $\begin{array}{l}\text { mucosal } \\
\text { length }\end{array}$ & villi length & $\begin{array}{l}\text { mucosal } \\
\text { length }\end{array}$ & villi length & $\begin{array}{l}\text { mucosal } \\
\text { length }\end{array}$ & villi length \\
\hline D1 (Control) & $\begin{array}{l}399.88 \pm 19.19 \\
\text { c }\end{array}$ & $\begin{array}{l}301 . \\
\mathrm{d}\end{array}$ & $\begin{array}{l}522.71 \pm 29.47 \\
\text { c }\end{array}$ & $\begin{array}{l}424 \\
c\end{array}$ & $\begin{array}{l}294.20 \pm 14.82 \\
\mathrm{c}\end{array}$ & $\begin{array}{l}164.4 \\
b\end{array}$ \\
\hline D2 (1 & $\begin{array}{l}474.39 \pm 7.92 \\
b^{\mathrm{c}}\end{array}$ & $\begin{array}{l}386.91 \pm 3.67^{b} \\
\text { c }\end{array}$ & $\begin{array}{l}798.14 \pm 90.21 \\
\text { ab }\end{array}$ & $\begin{array}{l}612.12 \pm 22.42 \\
b\end{array}$ & $\begin{array}{l}518.56 \pm 26.10 \\
\mathrm{a}\end{array}$ & $\begin{array}{l}378.53 \pm 19.98 \\
\text { a }\end{array}$ \\
\hline $\begin{array}{l}\text { D3 }(10 \mathrm{~cm} \mathrm{BS}+5 \mathrm{~g} \\
\text { CA) }\end{array}$ & $\begin{array}{l}561.02 \pm 19.50 \\
\mathrm{a}\end{array}$ & $\begin{array}{l}449.93 \pm 10.11 \\
\text { b }\end{array}$ & $\underset{\mathrm{ab}}{873.00 \pm 70.47}$ & $\begin{array}{l}713.19 \pm 12.50 \\
\text { a }\end{array}$ & $\underset{\mathrm{ab}}{460.66 \pm 21.14}$ & $\begin{array}{l}380.60 \pm 42.39 \\
\mathrm{a}\end{array}$ \\
\hline $\begin{array}{l}\text { D4 }(10 \mathrm{~cm} \text { BS+10g } \\
\text { CA) }\end{array}$ & $569.75 \pm 6.77^{a}$ & $\begin{array}{l}496.01 \pm 14.45 \\
\text { a }\end{array}$ & $\begin{array}{l}896.58 \pm 46.54 \\
\text { a }\end{array}$ & $\begin{array}{l}739.07 \pm 19.99 \\
\text { a }\end{array}$ & $\begin{array}{l}\mathbf{5 0 3 . 3 7} \pm 37.04 \\
\text { a }\end{array}$ & $\begin{array}{l}\text { 374.82 } \pm 33.47 \\
\text { a }\end{array}$ \\
\hline
\end{tabular}




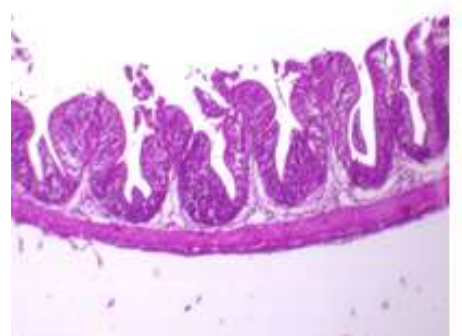

1- Duodenum normal vili length

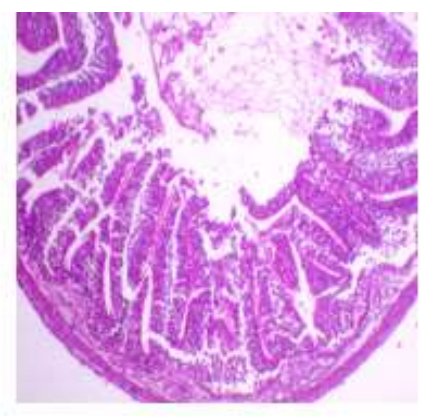

2- jejunum normal vili length 3- Ileum normal mucosal lining

Fig. (1): showed normal duodenum, jejunum and ileum in control.

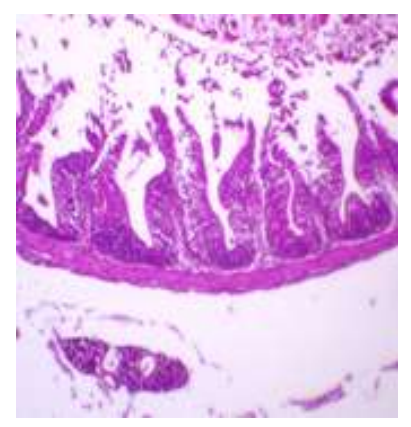

1- Duodenum normal vili length

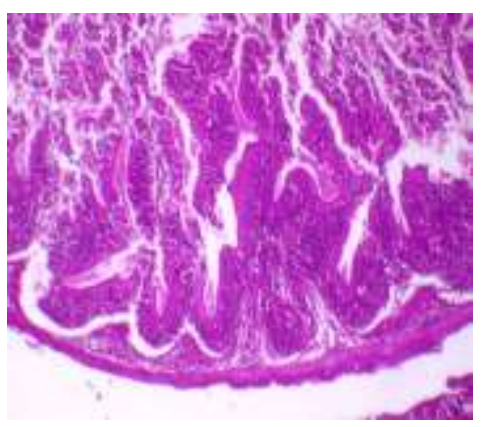

2- jejunum normal vili length

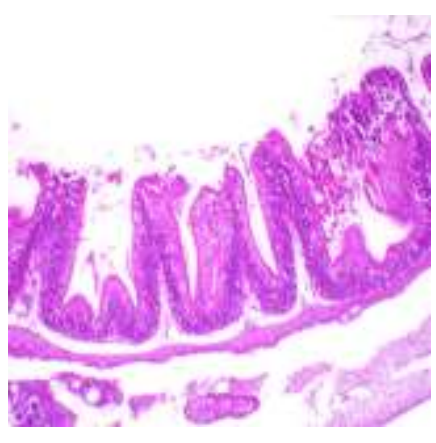

3- Ileum normal mucosal lining

Fig. (2): showed normal duodenum, jejunum and ileum in D2 supplemented with10 $\mathrm{cm}$ Bacillus subtilis. 
Hussein et al., 2019; Egy.J.Aquac. 9 (2):27-47

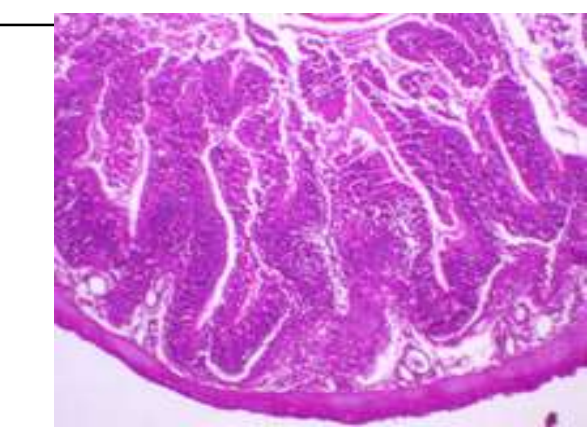

1-duodenum increase the villi length

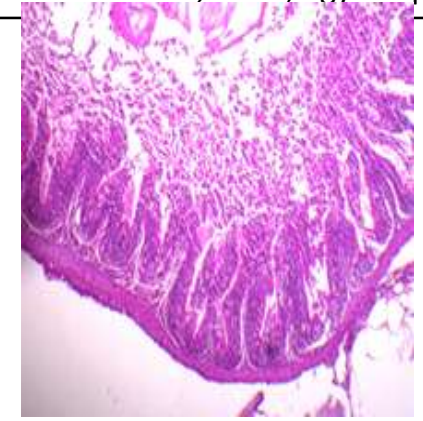

2- jejunum increase the villi length

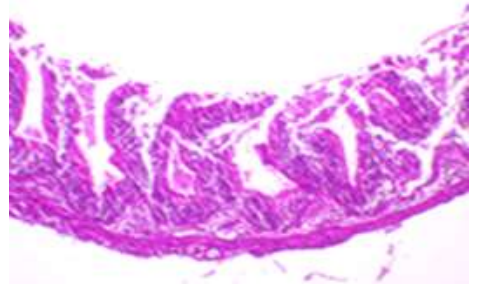

3- ilium normal mucosal lining

Fig. (3): showed increase in length of villi in duodenum and jejunum and normal mucosal lining in ileum D3 supplemented with $10 \mathrm{~cm}$ Bacillus subtilis $+5 \mathrm{~g}$ acetic acid.

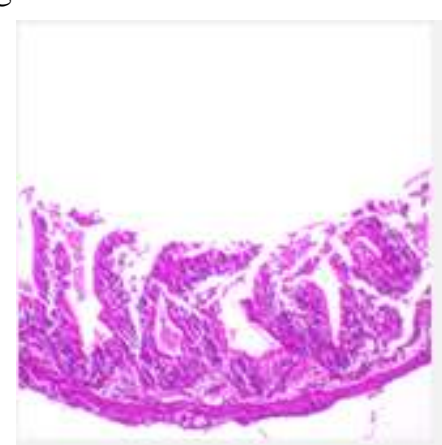

1- Jejunum increase the villi length
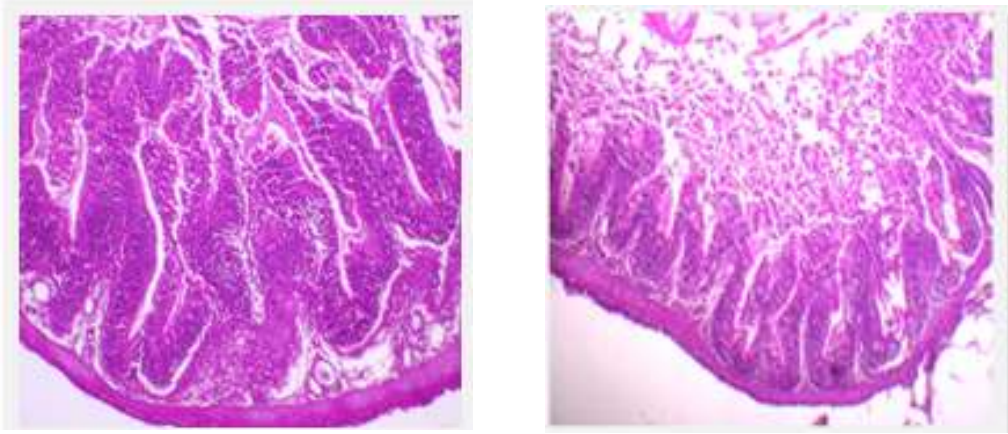

2- ilium normal mucosal lining

3- duodenum increase the villi length

Fig. (4): showed increase in length of villi in duodenum and jejunum and normal mucosal lining in ileum (D4) supplemented with $10 \mathrm{~cm}$ Bacillus subtilis $+10 \mathrm{~g}$ acetic acid. 


\section{DISCUSSION}

In the present study addition of Bacillus subtilis (BS) at a rate $10 \mathrm{~cm} / \mathrm{kg}$ diet, $10 \mathrm{~cm}(\mathrm{BS})+5 \mathrm{~g}$ citric acid $/ \mathrm{kg}$ diet, $10 \mathrm{~cm}(\mathrm{BS})+10 \mathrm{~g}(\mathrm{CA}) / \mathrm{kg}$ diet alleviated some of these negative effects. Adding of Bacillus subtilis and citric acid in the diets increased the growth performance such as Weight gain, Average daily gain, Specific growth rate and Condition factor, also, enhanced feed utilization such as, Feed efficiency, Protein retention, Protein efficiency ratio, Protein productive value and reduced the FCR, also, this addition in diets showed improvement in body chemical composition in fish. The obtained results are similar to those reported by (He et al (2013) in hybrid tilapia, Ai et al (2011) in Larimichthys crocea, Bairagi et al (2004) in Labeo rohita (Hamilton), Telli et al (2014) in Nile tilapia, Ng et al (2014) in red hybrid tilapia, Baruah et al (2005) in Labeo rohita (Hamilton), Khajepour and Hosseini (2012) in Beluga (Huso huso) and Su et al (2014) in white shrimp. Results of Liu et al. (2012) indicated that feed of fish in diets contain $10^{4}, 10^{6}$, and $10^{8} \mathrm{CFU}$ g- 1 B. subtilis showed improvement significant in growth performance and feed conversion ratio. Results of Ai $\boldsymbol{e t}$ al. (2011) showed that at each dietary FOS level and dietary supplementation of $1.35 \times 107 \mathrm{cfu}^{-1} B$. Subtilis significantly increased the specific growth rate $(\mathrm{SGR})(\mathrm{P}<0.01)$ and feed efficiency ratio (FER) $(\mathrm{P}<0.05)$ compared with the groups without $B$. subtilis supplementation. Bairagi et al. (2004) indicated that diets formulated with $40 \%$ Leucaena leaf meal and bacteria B. subtilis resulted in improvement growth performance and feed utilization, (feed efficiency ratio, protein efficiency ratio, apparent net protein utilization) of rohu fingerlings (Labeo rohita Ham.). Daniels et al. (2010) demonstrated that used diet containing Bacillus spp+MOS in feed of larval Homarus gammarus had improved significantly $(\mathrm{P}<0.01)$ weight gain, carapace length, weight to carapace length ratio, specific growth rate (SGR), food conversion ratio (FCR) and post-larval condition, compared to all other groups. Lin et al. (2012) who revealed that additive chitosan oligosaccharides and Bacillus coagulans in diets of Cyprinus carpio koi lead to improvement of final weight, specific growth rate (SGR) and feed conversion ratio (FCR). In contrast, Khajepour and Hosseini (2012) revealed that additive citric acid in diets of Beluga, Huso huso showed increasing in growth performance (final weight, weight gain and specific growth rate) and feed utilization (Protein efficiency ratio and decreased feed conversion ratio and increased the protein and phosphorus digestibility. Su et al. (2014) indicated that used citric acid in diets of white shrimp lead to increase of weight gain and decreased of feed conversion 
ratio. The enhanced in growth performance and nutrients digestibility's by dietary citric acid was also reported in tilapia, O. niloticus $x$ O. aureus (Pan et al. 2004). Adding citric acid a rate $10.0 \mathrm{~g} \mathrm{~kg}^{-1}$ in diet of $O$. niloticus $x$ O. aureus showed increased pepsin activity by $29.6 \%$ (Li et al. 2009). Improvement in growth performance and feed utilization in this study due to Bacillus subtilis and citric acid increased the villi length in duodenum and jejunum in intestine this lead to increased the absorption surface and therefore increased utilization of food and reflected on the growth and health of fish. Also, may have contributed to the increase on protease and amylase activity in intestine. This is likely because of the changes in intestinal $\mathrm{pH}$ by citric acid, as it has been reported that $\mathrm{pH}$ of digest is also a factor to influence CCK release and exocrine pancreatic secretion. In addition, the effect of citric acid on metal ion release may account for the changes of amylase in tilapia intestine (Li et al. 2009). Also, organic acids inhibited the harmful microorganisms to improve microecosystem (Øverland et al. 2008; Partanen and Mroz 1999) and reduced the intestinal $\mathrm{pH}$ value to enhance the reproduction of beneficial bacteria (Knarreborg et al. 2002; Partanen and Mroz 1999). It has been proved that CA can inhibit the adhesion of Escherichia coli with disturbing DNA synthesis in nucleus (Gedek et al. 1993).

\section{Conclusion}

In the present study was best treatment D4 $(10 \mathrm{~cm} B S+10 \mathrm{~g} \mathrm{CA})$ increasing in growth performance (final weight, weight gain and specific growth rate) and feed utilization.

\section{References}

A.O.A.C. (2005). Official methods of analysis of AOAC International. AOAC International.

Ai, Q., Xu, H., Mai, K., Xu, W., Wang, J., \& Zhang, W. (2011). Effects of dietary supplementation of Bacillus subtilis and fructooligosaccharide on growth performance, survival, non-specific immune response and disease resistance of juvenile large yellow croaker, Larimichthys crocea. Aquaculture, 317(1-4), 155-161.

Akhter, N., Wu, B., Memon, A. M., \& Mohsin, M. (2015). Probiotics and prebiotics associated with aquaculture: a review.Fish \& shellfish immunology, 45(2), 733-741.

Annet, C. S. (1985). A model to facilitate optimal aquaculture production by quantitatively relating fish growth to feed and other environmental resources. Ph.D., Thesis, Michigan State University, USA. 
Bairagi, A., Sarkar Ghosh, K., Sen, S. K., \& Ray, A. K. (2004). Evaluation of the nutritive value of Leucaena leucocephala leaf meal, inoculated with fish intestinal bacteria Bacillus subtilis and Bacillus circulans in formulated diets for rohu, Labeo rohita (Hamilton) fingerlings. Aquaculture Research, 35(5), 436-446.

Bairagi, A., Sarkar Ghosh, K., Sen, S.K., Ray, A.K., 2004. Evaluation of the nutritive value of Leucaena leucocephala leaf meal, inoculated with fish intestinal bacteria Bacillus subtilis and Bacillus circulans in formulated diets for rohu, Labeo rohita (Hamilton) fingerlings. Aquac. Res. 35, 436-446

Bancroft, J. D., Floyd, A. D., \& Suvarna, S. K. (2013). Bancroftl's Theory and Practice of Histological Techniques.

Baruah, K., Pal, A. K., Sahu, N. P., Jain, K. K., Mukherjee, S. C., \& Debnath, D. (2005). Dietary protein level, microbial phytase, citric acid and their interactions on bone mineralization of Labeo rohita (Hamilton) juveniles. Aquaculture Research,36(8), 803-812.

Brenes, A., Viveros, A., Arija, I., Centeno, C., Pizarro, M., \& Bravo, C. (2003). The effect of citric acid and microbial phytase on mineral utilization in broiler chicks. Animal Feed Science and Technology, 110(1-4), 201-219.

Castell, J. D. and Tiews, K. (1980). Report of the EIFAC, IUNS and ICES Working Group on the Standardization of Methodology in Fish Research. Hamburg, FRG, Germany, IFAC Tech., (3): 24.

Cohen, L. A., Zhao, Z., Pittman, B., \& Scimeca, J. (2003). Effect of soy protein isolate and conjugated linoleic acid on the growth of Dunning R-3327-AT-1 rat prostate tumors. The Prostate, 54(3), 169-180.

Daniels, C. L., Merrifield, D. L., Boothroyd, D. P., Davies, S. J., Factor, J. R., \& Arnold, K. E. (2010). Effect of dietary Bacillus spp. and mannan oligosaccharides (MOS) on European lobster (Homarus gammarus L.) larvae growth performance, gut morphology and gut microbiota. Aquaculture, 304(1-4), 49-57.

Davies, S.J. and Morris, P.C. (1997). Influence of multiple amino acid supplementation on the performance of rainbow trout, Oncorhynchus mykiss (walbaum), fed soya based diets. Aqua Res., 28: 65- 74.

Duncan, D. B. (1955). Multiple range and multiple $F$ tests. Biometrics, 11 (1), 1-42. 
FAO (2004). The state of world fisheries and aquaculture. Rome, Italy; 2004. p. 14e17

FAO (2006). State of world aquaculture 2006. Rome: FAO Fisheries; 2006. Technical Paper; No. 500

Gauthier, R. (2005). Organic acids and essential oils, a realistic alternative to antibiotic growth promoters in poultry. Animal world, 148-157.

Gedek B, Roth FX, Kirchgessner M (1993). Influence of fumaric acid, hydrochloric acid, sodium formate, tylosin and toyocerin on the microflora in different segment of the gastrointestinal tract. Pig News and Information 14:178.

He, S., Zhang, Y., Xu, L., Yang, Y., Marubashi, T., Zhou, Z., \& Yao, B. (2013). Effects of dietary Bacillus subtilis C-3102 on the production, intestinal cytokine expression and autochthonous bacteria of hybrid tilapia Oreochromis niloticus $9 \times$ Oreochromis aureus ${ }^{\lambda}$. Aquaculture, 412, 125-130.

Hoa, N. T., Baccigalupi, L., Huxham, A., Smertenko, A., Van, P. H., Ammendola, S., ... \& Cutting, S. M. (2000). Characterization of Bacillus species used for oral bacteriotherapy and bacterioprophylaxis of gastrointestinal disorders. Applied and environmental microbiology, 66(12), 5241-5247.

Khajepour, F., \& Hosseini, S. A. (2012). Citric acid improves growth performance and phosphorus digestibility in Beluga (Huso huso) fed diets where soybean meal partly replaced fish meal. Animal feed science and technology, 171(1), 68-73.

Knarreborg, A., Miquel, N., Granli, T., \& Jensen, B. B. (2002). Establishment and application of an in vitro methodology to study the effects of organic acids on coliform and lactic acid bacteria in the proximal part of the gastrointestinal tract of piglets. Animal Feed Science and Technology, 99(1-4), 131-140.

Lazado, C. C., \& Caipang, C. M. A. (2014a). Mucosal immunity and probiotics in fish. Fish \& shellfish immunology, 39(1), 78-89.

Lazado, C. C., \& Caipang, C. M. A. (2014b). Bacterial viability differentially influences the immunomodulatory capabilities of potential host-derived probiotics in the intestinal epithelial cells of Atlantic cod Gadus morhua. Journal of applied microbiology,116(4), 990-998.

LENG, X. J., LUN, F., LI, X. Q., WANG, Z. Q., \& XU, K. J. (2006). Effects of citric acid on growing performance and nutrients digestibility 
of allogynogenetic crucian carp [J]. Journal of Shanghai Fisheries University, 2, 009.

Li, J. S., Li, J. L., \& Wu, T. T. (2009). Effects of non-starch polysaccharides enzyme, phytase and citric acid on activities of endogenous digestive enzymes of tilapia (Oreochromis niloticus $\times$ Oreochromis aureus). Aquaculture Nutrition, 15(4), 415-420.

Lin, S., Mao, S., Guan, Y., Luo, L., Luo, L., \& Pan, Y. (2012). Effects of dietary chitosan oligosaccharides and Bacillus coagulans on the growth, innate immunity and resistance of koi (Cyprinus carpio koi). Aquaculture, 342, 36-41.

Liu, C., Chiu, C., Wang, S., Cheng, W., 2012. Dietary administration of the probiotic, Bacillus subtilis E20, enhances the growth, innate immune responses, and disease resistance of the grouper, Epinephelus coioides. Fish \& Shellfish Immunology 33, 699-706

Lundén, T., Lilius, E. M., \& Bylund, G. (2002). Respiratory burst activity of rainbow trout (Oncorhynchus mykiss) phagocytes is modulated by antimicrobial drugs. Aquaculture, 207(3-4), 203-212.

Marias, J.F.K. and Kissil, G.E. (1979). The influence of energy level on the feed intake, growth, food conversion and body composition of Sparus aurata. Aquaculture 17: 203219.

Nayak, S. K. (2010). Probiotics and immunity: a fish perspective. Fish \& shellfish immunology, 29(1), 2-14.

Ng, W. K., Kim, Y. C., Romano, N., Koh, C. B., \& Yang, S. Y. (2014). Effects of dietary probiotics on the growth and feeding efficiency of red hybrid tilapia, Oreochromis sp., and subsequent resistance to Streptococcus agalactiae. Journal of Applied Aquaculture, 26(1), 22-31.

NRC (1993). Nutrient requirements of fish. Committee on Animal Nutrition Board on Agriculture. National Academy Press, Washington DC., USA. Pp:114.

Øverland, M., Granli, T., Kjos, N. P., Fjetland, O., Steien, S. H., \& Stokstad, M. (2000). Effect of dietary formates on growth performance, carcass traits, sensory quality, intestinal microflora, and stomach alterations in growing-finishing pigs.Journal of Animal Science, 78(7), 1875-1884.

Øverland, M., Kjos, N. P., Borg, M., Skjerve, E., \& Sørum, H. (2008). Organic acids in diets for entire male pigs: Effect on skatole level, 
microbiota in digesta, and growth performance.Livestock Science, 115(2-3), 169-178.

Pan, Q., Tan, Y. G., Bi, Y. Z., \& Zheng, S. X. (2004). Effects of citric acid on growth, whole body composition and activities of digestive enzymes in hybrid tilapia Oreochromis niloticus 9 O. aureus. J Fish Sci Chin, 11, 344-348.

Pandey, A., \& Satoh, S. (2008). Effects of organic acids on growth and phosphorus utilization in rainbow trout Oncorhynchus mykiss. Fisheries Science, 74(4), 867-874.

Partanen, K. H., \& Mroz, Z. (1999). Organic acids for performance enhancement in pig diets. Nutrition Research Reviews, 12(1), 117-145.

Partanen, K., Siljander-Rasi, H., Alaviuhkola, T., Suomi, K., \& Fossi, M. (2002). Performance of growing-finishing pigs fed medium-or highfibre diets supplemented with avilamycin, formic acid or formic acidsorbate blend. Livestock Production Science, 73(2-3), 139-152.

Ram C. Bhujel (2014). A Manual for Tilapia Business Management. Aquaculture and Aquatic Resources Management (AARM) School of Environment, Resources and Development (SERD) Asian Institute of Technology (AIT) Pathumthani, Thailand

Recker, W.E. (1975). Computation and interpretation of biological statistics of fish populations. Fish. Res. Board Can. Bull., 191: 1-382.

Sarker, S. A., Satoh, S., \& Kiron, V. (2005). Supplementation of citric acid and amino acid-chelated trace element to develop environmentfriendly feed for red sea bream, Pagrus major.Aquaculture, 248(1-4), 311.

SPSS, S. (2011). for Windows. Chicago: SPSS Inc.

Su, X., Li, X., Leng, X., Tan, C., Liu, B., Chai, X., \& Guo, T. (2014). The improvement of growth, digestive enzyme activity and disease resistance of white shrimp by the dietary citric acid.Aquaculture international, 22(6), 1823-1835.

Subasinghe, R. P. (2005). Epidemiological approach to aquatic animal health management: opportunities and challenges for developing countries to increase aquatic production through aquaculture. Preventive veterinary medicine, 67(2-3), 117-124.

Sugiura, S. H., Gabaudan, J., Dong, F. M., \& Hardy, R. W. (2001). Dietary microbial phytase supplementation and the utilization of phosphorus, trace minerals and protein by rainbow trout [Oncorhynchus 
mykiss (Walbaum)] fed soybean meal-based diets. Aquaculture Research, 32(7), 583-592.

Tacon, A. (1987).The nutrition and feeding of farmed fish and shrimp a training manual. $\mathrm{V}$ 61. 1. The essential nutrients. FAO.PP. 117-130.

Telli, G. S., Ranzani-Paiva, M. J. T., de Carla Dias, D., Sussel, F. R., Ishikawa, C. M., \& Tachibana, L. (2014). Dietary administration of Bacillus subtilis on hematology and non-specific immunity of Nile tilapia Oreochromis niloticus raised at different stocking densities. Fish \& shellfish immunology, 39(2), 305-311.

Verschuere, L., Rombaut, G., Sorgeloos, P., \& Verstraete, W. (2000). Probiotic bacteria as biological control agents in aquaculture. Microbiology and molecular biology reviews, 64(4), 655671. 


\section{التأثير المشترك للبريبيوتك والبروبيوتك على أداء النمو والإستقادة من الغذاع فى أسماك

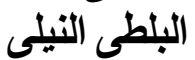

\section{محسن صالح حسين ، أحمد محمد أحمد الزيات ، محمد محمود سيداحمد النوسانى}

شعبة إنتاج الأسماك، قسم الإنتاج الحيو انى، كلية الزر اعة ، جامعة الأزهر، القاهرة

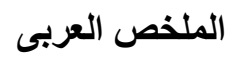

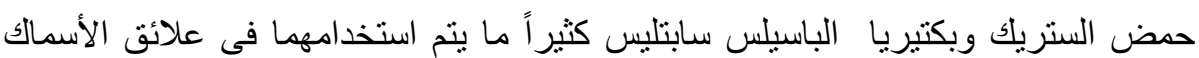
كبريبيوتيك وبروبيوتيك حيث يتم تحسين النمو والإستفادة الغذائية وتزيد معدلات الإستجابة الإنيا

وتهذف هذه الدر اسة إلى معرفة استخدام البكتيريا مضافة إلى حمض الستريك و البكتيريا وحدها

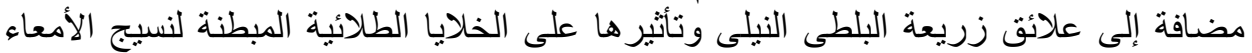

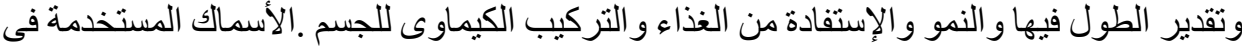

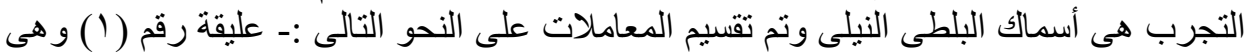

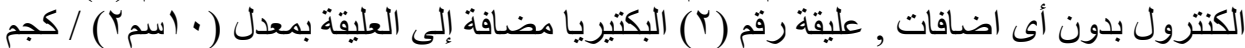

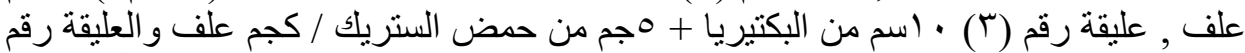

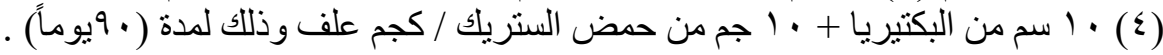

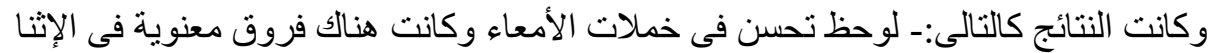

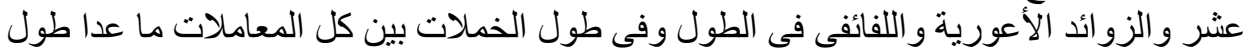

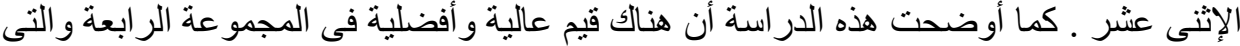

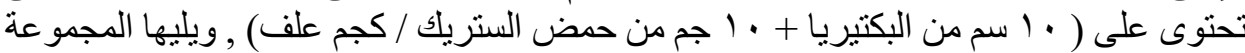

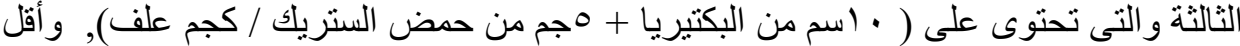

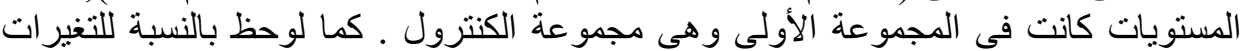

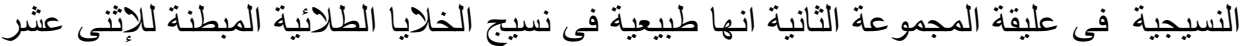

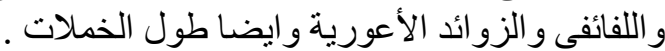

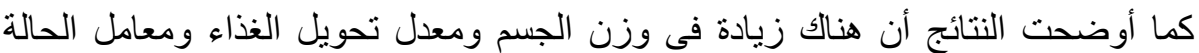

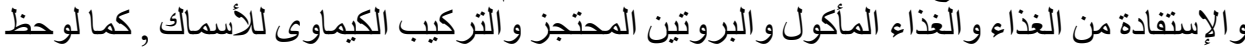

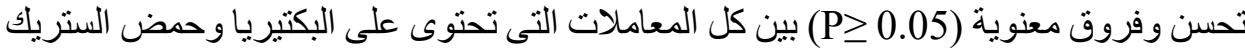
وذللك مقارنة بمجمو عة الكنترول .

لهذا ولكل ما سبق نوصى بإضافة حمض الستريك وبكتيريا الباسيلس في علائق الأسماك لأنها

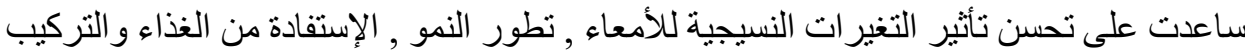

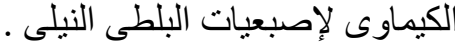

